\title{
Belphégor
}

Littérature populaire et culture médiatique

10-3 | 2011

Peter Pan

\section{Shaswati Mazumdar, Insurgent Sepoys. Europe views the Revolt of 1857}

\section{Vittorio Frigerio}

\section{(2) OpenEdition \\ 1 Journals}

\section{Electronic version}

URL: http://journals.openedition.org/belphegor/411

DOI: 10.4000/belphegor.411

ISSN: 1499-7185

Publisher

LPCM

\section{Printed version}

Date of publication: 10 January 2011

\section{Electronic reference}

Vittorio Frigerio, «Shaswati Mazumdar, Insurgent Sepoys. Europe views the Revolt of 1857 », Belphégor [Online], 10-3 | 2011, Online since 10 January 2013, connection on 23 September 2020. URL : http:// journals.openedition.org/belphegor/411 ; DOI : https://doi.org/10.4000/belphegor.411

This text was automatically generated on 23 September 2020.

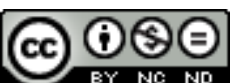

Belphégor est mis à disposition selon les termes de la Licence Creative Commons Attribution - Pas d'Utilisation Commerciale - Pas de Modification 4.0 International. 


\title{
Shaswati Mazumdar, Insurgent Sepoys. Europe views the Revolt of 1857
}

\author{
Vittorio Frigerio
}

\section{REFERENCES}

Shaswati Mazumdar, Insurgent Sepoys. Europe views the Revolt of 1857, New Delhi, Routledge, 305 p., ISBN: 978-0-415-59799-9

1 The main goal of this book is to obviate to "the lack of attention to the international dimensions of the [1857] revolt" (p. 4). As such, it offers "a first look at some of these European responses" (ibid.) and has the merit of adopting a very wide lens, affording considerable attention to novelistic interpretations of the events - often intended for a mass audience - that until recent times would have been considered unworthy as objects of serious academic study. The result is a fascinating and multifaceted collection that will prove particularly instructive for Western readers.

2 Claudia Reichel ("German Responses: Theodor Fontane, Edgar Bauer, Wilhelm Liebknecht") examines first of all the articles written by the famous German writer Theodor Fontane for the Neue Preussischer Zeitung as a correspondent from London, noting his sympathies for the Indian cause and how, paradoxically, the conservatives supported the Russian autocracy (wrongly accused of fostering the Indian rebellion) while the liberals were on the side of British colonialism, seen as "the trailblazer of western civilization" (p. 25). Fontane ended up resigning his position with the paper, since his view of the rebellion went against the paper's official editorial line. His letters are testimony to his highly negative opinion of British colonialism, which he sees as only driven by profit and hiding behind the alibi of religion and progress.

3 The writings of German publicist Edgar Bauer, who had fled to England after the revolution of 1848, are touched upon, as are those of Wilhelm Liebknecht, also a refugee, who would later be amongst the founders of Germany's Social Democratic 
Party. Both paid particular attention to "the repercussions that the events in India could have on British society" (p. 40).

4 Nicola Frith ("French Counter-narratives: Nationalisme, Patriotisme and Révolution") focuses on "the nomenclatures found in 19th-century French-language writing, including journalistic, historical, travel and fictional accounts, all of which consciously and/or subconsciously employ what can be seen as counter-descriptive terms to Anglocentric narratives of the so-called "mutiny"' (p. 43). Her main point in reviewing the various ways in which ideologically-charged definitions were used to minimize the importance of this historical event is that "Said's blanket approach to colonialist literature, which he defines in Orientalism (1978) as a singular discourse, overlooks the counter-discourses inherent within 'western' writing" (p. 47-48). The article further explores "the extent to which French and British colonial discourse operate in competition with each other" (p.56), and how French depictions of the Indian "revolution" are simply expressions of nostalgia for their own loss of Indian colonies and self-serving representations of supposedly truly civilizing colonial expansion - this time in Africa.

Chiara Cherubini ("Freedom and Democracy: "The Revolt in Italian Press"”) analyses the Italian press in pre-unification times, showing "how the conservative press saw the revolt as an opportunity to denounce and delegitimise British power and expansionism as well as British moral guidance to those European patriots who were trying to subvert and overthrow the old monarchic regimes" (p. 640). The reading of a number of major papers from various regions of the country shows how the Indian events were read and used primarily as through the prism of domestic politics, in the absence of any real and widespread knowledge of that far-away, exotic country.

Vibha Maurya and Maneesha Taneja ("A View of the Revolt in the Spanish Press") offer a close reading of an article by a Spanish political commentator aiming to provide general information on India, but actually debating the consequences of the 1857 revolt from the standpoint of Spain's position as a declining colonial power in the Americas. Some affirmations take your breath away, such as the note on page 90 affirming: "Racial prejudice, as it exists in today's world, is exclusively a white man's attitude". Apart from this type of inconceivable generalization, the authors rightly define the means and the consequences of this supposedly "civilizing" task on the indigenous populations, ruthlessly brutalized by the colonizers. Their reading of this particular article, and through it of Spanish views of the mutiny, highlights the similarity in approach between the two colonialisms, with the Spaniards approving of the conquests of their neighbour (and former enemy) to the north, particularly because of the religious conversion of the subjugated peoples.

7 In her article "Hungarian Responses: Between Support and Disagreement", Margit Köves evokes the Hungarian responses to the Mutiny, suggesting that the Magyars understood the Indian happenings in terms of their own War of Independence (1848-49) and that "the 1857 Rebellion provided a context for understanding the Hungarian events in the form of universal laws of history" (p. 95). She analyses the coverage of the rebellion provided by four newspapers or various political orientations, showing how discourse around matters of Religion, culture, language and the extent of the Monarchy's power consistently mirrored the uneasy relationship between Hungary and the Austrian throne. 
8 Sarah Lemmen ("Czech Representations of India and the Rebellion, 1850-1930"), in a similar vein, shows how Czech society saw itself, with respect to the Habsburg monarchy, like India with respect to the British Crown. This was not as clear cut as with the previous example, as the Czech still did not quite see themselves as a nationality and therefore could not be "colonized" in quite the same manner. Representations of the insurrection in the press used to combine stereotypical images of "fearless" English generals and "bloodthirsty" Indian rebels with more sympathetic accounts of the widespread injustices suffered by the Indians. The Interwar Period (Czechoslovakia having been founded in 1918) saw the development of economic and cultural ties between the new country and India. Parallelisms between the "fate of the Czech and Indian nations, both anti-imperialist and repeatedly oppressed" (p. 123) continued on into present times.

9 Rashmi Joshi ("Bulgarska Dnevnitsa: A Bulgarian Response to the Uprising") analyses the reactions the events in India as presented in The Bulgarian Diary, a journal edited by Georgi Stoikov Rakovski, a well-known nationalist writer. Although relying mostly as is the case for a great part of the European press on British newspaper accounts, Rakovski pictures it as a symbolic equivalent of the Bulgarian situation within the Ottoman empire: "oppression could drive even a gentle and mild people to react strongly" (p. 128).

10 Part II, "Fact and Fiction", starts with an article by Anil Bhatti entitled "Retcliffe's Nena Sahib and the German Discourse on India". Hermann Ottomar Fredrich Goedsch was an ultra-conservative German journalist who wrote highly successful popular fiction under the English pseudonym of Sir John Retcliffe. In his novel on the rebellion, he mixes traditional topoï of the adventure novel with criticism of British exploitation and, paradoxically, a socio-darwinian outlook on the right of conquest by stronger nations. Nena Sahib's just revolt, supported by emissaries of other nations that have suffered because of British expansionism, gets out of hand, however, as his brutal, animal nature is unleashed. Colonialism is understood as an unnatural breach of a people's "culturally determined sphere of existence" (p. 149).

11 Carola Hilmes ("The Rebellion of an Indian Temple Dancer") presents another Rebellion-inspired German novel by an otherwise forgotten author, H. Brunner, who mixed "the conventional stereotypes of Orientalism" with "strong criticism of colonialism" (p. 152). This is a novel marked by a mix of fact and fiction, where the sensational elements dominate. The author analyzes gender and power relationships between the sexes and between races, and points out how the novel projects fin-desiècle European concerns on its exotic subject, diluting the anti-colonialist message by superimposing the public and the private realms. "Individual misconduct" (p. 168) ends up hiding the real social and political causes of the upheaval.

12 Flaminia Nicora's article "The Stirring Story of the Cipays: Italian Narrative Responses" aims "to circumscribe and outline this thin tradition of Italian historical novels" (p. 172) dealing with the rebellion, comparing this production with English novels on the same theme in order to identify their peculiarities. Amongst these we discover Aristide Calani's Scene dell'insurrezione Indiana (pre-unification: 1858), a novel constructed by "borrowing" large amounts of text, descriptions and information from sundry sources, often British, but providing an original view of the mutiny as a real war of independence and almost offering "an alternative mythography of the rebellion" (p. 179). The rest of the article is taken up by a joint analysis of novels by Guglielmo 
Stocco, Margherita Olliveri and Emilio Salgari, all of them adventure intended for young readers and published post-unification in a different political context, with Italy developing its own colonial ambitions.

Sharmistha Lahiri ("Remember Cawnepore: The 'Massacre' in the Voice of Three Italian Narrators") also focuses on Italian narratives of the mutiny: a missionary report, the novel by Calani, and a piece by well-known poet Guido Gozzano. These are seen as subjected to "a dual pull between the European gaze on the Asiatic and the Italian response vis-à-vis the British" (p. 191). They are presented as categories of discourse that interpret events differently according to their temporal distance from them and their recourse to primary sources, or, later, to "universal parameters" (p. 192) more remote from the actual happenings.

14 Alessandro Portelli ("Emilio Salgari's The Two Tigers: Exoticism, Anti-imperialism and Ambivalence" analyses one of Salgari's best and most read novels, finding in it a kind of "interesting and unusual" (p. 214) type of Orientalism, born of curiosity, openmindedness and fascination. Sandokan the pirate, the hero of the story, is himself an Oriental and it is through his eyes that the multiplicity and variety of conceptions of the Orient are revealed to the reader. Respect and admiration for Indian culture mix with revulsion at the brutality of British colonials in this novel by an author who has always had a soft spot for courageous and noble losers - a writer who is definitely "not automatically on the side of law and order" (p. 217).

15 Swati Dasgupta ("Lost in Translation: Jules Verne and the Indian Rebellion") reveals the many politically and ideologically-driven instances of censorship in Verne's English translations, in particular as to what concerns British actions in India. Nemo - an Indian prince and a leader of the 1857 uprising to all his French readers - is discovered in these apocryphal versions to be anything but, as "Verne was distorted with abandon by his English translators" (p. 228).

is still Jules Verne that offers Suchitra Choudury the subject matter for her article "A Great Insurrection: Jules Verne and British Mutiny Fiction". The focus this time is on the novel La Maison à vapeur, making much the same points as the previous article.

Everton V. Machado ("The Rebellion in a 19th-centur Indo-Portuguese Novel") presents what the author considers possibly "the first anti-colonial novel in the history of modern literature" (p. 251): Os Brahamanes, of the Goan writer Francisco Luiz Gomes. The novel adopts a liberal-catholic approach to denounce both the racism of the caste system and that of the British colonizers, while blaming the failure of the mutiny on the fact that it was a "revolt" inspired by vengeance rather than a true revolution driven by the will of a united people, such as the French Revolution. Ultimately, Gomes, an indigenous man who was fully integrated into Portuguese-Indian society, really advocates a fraternal, Christian-oriented type of colonialism, such as the image the Portuguese wanted to project, rather than the repressive and ruthless approach adopted by the British.

It is once again Gomes and his novel that are the subject of Balaji Ranganathan's article "Francisco Luiz Gomes's Os Brahamanes: The Uprising and Anglo-Indian Society", but here the focus shifts principally to the complex relationships between castes and the tensions between various groups (Brahmins, Christian converts, colonial authorities) and the influence of the introduction of "class and race in place of caste [...] within Anglo-Indian society" (p. 274). The author notes how the events quickly became arranged within a "romantic construct" that serves as a vehicle for the novelist's 
"universalistic liberal beliefs" (p. 276) and concludes by affirming that "the humanistic vision of Gomes needs to be interrogated" (p. 277) in the face of the reality of Portuguese, and later British, domination of India.

Vijaya Venkataraman ("El dragón del fuego: A Dramatic Representation of the Revolt") treats of a play by Spanish playwright's Jacinto Benavente, which is seen as a means to "write on a host of contentious themes from within the framework of accepted [fictional] norms" (p. 279). A detailed description of the play's convoluted plot leads to a comparison with the actual events of the mutiny and a discussion of the representation of India within Spanish culture. The author concludes that this play, written fifty years after the events, is marked by a romantic vision of the Orient typical of the 19th century, while it attempts to offer "a critique of colonial discourse" (p. 288) within the ongoing debate on Spain's own colonial enterprises in Latin America.

Some more care could have been taken in the proofreading of a few articles that are not exempt from stylistic problems. The reappearance of the same subjects in various studies also causes a number of repetitions that, while probably unavoidable, can be felt as needless. In spite of these minor problems, we have here a very valuable volume that has much to teach the reader both in terms of the actual events surrounding the 1857 revolt and its reception and representation in Europe, particularly in the field of mass literature. In the introduction, the Editor presents the collection as "part of a larger effort to document representations of the 1857 revolt in non-English speaking Europe, an effort started in 2007 at the Department of Germanic and Romance Studies of the University of Dehli", and a kind of "curtain raiser" (13-14). This volume gives many reasons to look forward to the works that will likely follow. 